\title{
EFFECTS OF CORPORAL PUNISHMENT ON DISCIPLINARY CONTROL OF SECONDARY SCHOOL STUDENTS IN CALABAR METROPOLIS OF NIGERIA
}

EKPENYONG E. EKANEM AND ANIEFIOK O. EDET

(Received 25, January 2013; Revision Accepted 15, February 2013)

\begin{abstract}
Administration of corporal punishment in secondary schools tends to be cruel, inhuman and could result in child abuse. Therefore, the purpose of this study was to determine the effects of the use of corporal punishment on the disciplinary control of secondary education students in Calabar Metropolis of Nigeria. The study was designed to provide baseline information for micro policy management on education in order to enhance disciplined behaviour of students at secondary education level. Two research questions and one hypothesis were applied to guide the study while related literatures were reviewed. A sample size of 250 was drawn from a population of 1,666 secondary school teachers using a stratified random sampling technique. A well validated 18-item questionnaire was designed using the Likert Scale to collect information from respondents. Data were statistically analyzed using percentage, mean and independent t-test statistics. Results obtained revealed that corporal punishment was most frequently used among varieties of school punishment but it was not effective in disciplinary control of students in secondary schools. There was a significant difference in the use of corporal punishment on disciplinary control between public and private secondary school students. Based on these findings, appropriate recommendations were made.
\end{abstract}

KEY WORDS: Disciplinary Control, Indiscipline, Behaviour, Corporal Punishment, Secondary School.

\section{INTRODUCTION}

A school like any other business organization is expected to direct its personnel towards acceptable attitude and behavior, within and outside the organization. This will lead to secure peaceful environment and guide activities of organizational members. According to Kayode (2010), disciplinary control is an element of managerial task necessary for effective management of individuals in the school system it makes them well adjusted, happy and tenured towards achievement of school goals. Studentsô discipline being part of the socialization is given priority since they are priceless and most essential assets in education. Indiscipline of students (collective misbehaviour) therefore attracts punishment in an attempt to deal with repeated misbehavior capable of threatening the success of teaching-learning process. Most often, corporal punishment is inflicted on students but with caution since such chastisement may be sadistic, cruel and even excessive (Rigby, 2011). Based on this, the researcher needs to investigate the effects of corporal punishment on the disciplinary control of secondary school students in Calabar Metropolis of Nigeria.

School discipline refers to a systematic instruction given to a disciple (students) to enable him follow a particular code of conduct. Disciplinary control implies making a person observe moral and social principles to the doing of what is right and good. Adesina (2008), adduce school disciplinary control when students

Ekpenyong E. Ekanem, Department of Educational Administration and Planning, University of Calabar, Calabar-Nigeria

Aniefiok O. Edet, Department of Educational Administration and Planning, University of Calabar, Calabar, Nigeria 
are taught to respect the school authority, observe school laws/regulations; and maintain good behavioural standards. Disciplined behaviour may take the form of self- sacrifice, diligence, co-operation, integrity, truthfulness, sympathy and patriotism (Reyes, 2010).

Educational administrators are to consciously instill these characteristic features in students since discipline is a pre-requisite to almost everything a school has to offer students.

Indiscipline on the other hand refers to a situation where a child sets aside school regulations, and school laws to do what he likes. Causes of studentsô indiscipline may include ineffective teaching, lack of facilities, lack of morals, poor learning attitude, harsh school rules and regulations, poor home training, insincerity and lack of devotion to duty. Nathan (2012) posits major symptoms of school indiscipline to be lateness, truancy, unrest, fighting, noise making, mass disobedience, absenteeism, vadalization, examination malpractices and violent demonstration. These are destructive and undeserving elements of progress, and training or mode of life. Education managers are to prevent awkward and uncivilized behaviour often demonstrated by students, especially with the recent increase in school enrolment.

The commonest tool of disciplinary control in Nigeria is corporal punishment (Chianu, 2001). It involves intentional application of physical force with caution as a means of changing unwanted behavior. This means, that it needs to be reasonably administered according to regulations and laws of the school management board, the proportion of the offence and ability of the child (age, size, health and not excessive). Some of the common forms of corporal punishment in practice include flogging, slapping, spanking, punching and kicking. Others include hitting with objects, kneeling down, punching and prevention of excretion (feaces and urine). The right and authority of a school administrator and teacher to inflict punishment in students for offences that breach school rules and regulations is enhanced by section 34 subsection (1) of the 1999 constitution of Federal Republic of Nigeria. This section specifies people $\hat{\Phi}$ right to personal liberty and instances in which a person who has not attained the age of eighteen may be deprived of his right to personal liberty specifically for educative and welfare purposes.
Other types of common punishment practices in schools include sweeping, grass cutting, screaming, cleaning of toilet, stumping, repairing of damage property and law enforcement agents. To Saunder (2003), school punishment includes picking of papers from play grounds, isolation or exclusion, tidying up of class rooms; withdrawal of some privileges and detention within some task. Mental punishments are those of personal criticism, ridicule and sarcasm while verbal ones include order of cease, threat, abuse and reprimand (Rigby, 2011). Suspension, expulsion and physical punishment and also added types. Teachers are to adopt appropriate code of conduct as authorized by Ministry of Education and work within the scope of their employment (protected by vicarious liability).

The scope of the research is delimited to the study in secondary schools in Calabar metropolis and assessed by teachers domiciled in these schools. The significance of the study will be seen in its satisfaction or otherwise of the objectivity and rationalization to the use of corporal punishment. The government, education administrators, students and parents will equally find the study useful since discipline is essential for achievement of educational objectives. Fundamentally, school heads are to ensure strict compliance of regulations guiding disciplinary matters in order to avoid unwarranted litigation from parents of students.

\section{Statement of the Problem}

The problem of study centres around the noticeable unprecedented mass failure among the secondary school students in Calabar Metropolis of Nigeria. The intensity of the mass failure is a confirmation of poor study habit of the students occasioned by the seemingly weak disciplinary control at the secondary school level. The fact that corporal punishment is regarded by some people as cruel, inhuman and subjection to child abuse, gives teachers and school heads limited scope to stand in-loco-parentis to students under their charge in terms of safety and discipline. This controversial situation compels school administrators to accept the position that corporal punishment does not discourage misbehaviour but reinenforce it. The consequence is that secondary school students lack disciplined behaviour which can guarantee good academic performance. A perceived way out is to identify an acceptable common model of 
discipline which can be utilized to promote good behaviour and instill notions of responsibility in students for good performance. This investigation wishes to contribute to fill the existing literature. The question remains: can corporal punishment rather than any other measure guarantee disciplinary control of secondary school students in Calabar Metropolis to their good performance in academics? This study is designed to find an answer to this poser.

\section{Purpose of the Study}

The purpose of the study was to determine the effects of corporal punishment on the disciplinary control of secondary school students in Calabar Metropolis to their good performance in academics. Specifically, the study was designed:

1. To find out the extent to which corporal punishment could be used for the disciplinary control of secondary school students.

2. To determine the level of effectiveness of corporal punishment on the disciplinary control of secondary school students.

3. To ascertain the difference in the use of corporal punishment on the disciplinary control between the public and private secondary school students.

\section{Research Questions}

1. What is the relative frequency of the use of corporal punishment on disciplinary control of secondary school students?

2. What is the level of effectiveness of corporal punishment on the disciplinary control of secondary school students?

\section{Hypothesis}

There is no significant difference in the use of corporal punishment on disciplinary consol between the public and private secondary school students.

\section{Methodology}

This study adopted a description survey research design. The study area was Calabar Metropolis in Cross River State of Nigeria. It is made up of Calabar Municipality and Calabar South Local Government Area located along the southern axis of Cross River State of Nigeria. It covered 22 secondary schools located therein, 14 were public while 8 were private. A sample size of 250 teachers comprising 130 public secondary school teachers and 120 private secondary school teachers was drawn from the teachersô population of 1666 using stratified random sampling technique. The stratification was done along the public and private owned secondary schools from which simple random sampling method by ballotry was used to select 15 percent of the teacher $\hat{\mathbf{s}}$ population as samples for both public and private teachers population.

A researcher constructed instrument called ñCorporal Punishment for Disciplinary Control. Questionnaire (̃) (CPFDCQ) was used for data collection. The instrument has 18 items of four-point Likert scale scored as strongly agree (4 points), agree (3 points), strongly disagree (2 points) and disagree (1point). It was designed for teachers to find out relevant information about corporal punishment for solving the problem of studentsô disciplinary control of secondary schools in Calabar Metropolis of Nigeria.

The instrument was face-validated by experts in school administration and one other expert in measurement and evaluation. The reliability of the instrument was ascertained using Spearman Rank Order Correlation to give 0.68. This figure was considered adequate in achieving the research objectives.

The administration of the instrument was done by the researcher and his trained research assistance. The percentage response was 100 percent. The data collected were analyzed using statistical techniques of percentages and mean on research questions while independent t-test analysis was used to test the hypothesis.

\section{Data Analysis and Results}

The information gathered from the secondary school teachers were subjected to descriptive statistics using tables percentage, mean rating and independent t-test. The analyses were shown in table 1, 2 and 3 .

\section{Research Question One}

What is the relative frequency of the use of corporal punishment on disciplinary control of secondary school students? Mean was used to rank the responses of the teachers on the types of punishment used on disciplinary control in the secondary schools. Summaries of the results were presented on table 1.

Table 1 revealed that the secondary school teachers rated corporal punishment as a 
model with the highest frequency of 0.85 . Other forms of punishment attracted mean ranging from
0.82 to 0.02 with rank order of $2^{\text {nd }}$ to $17^{\text {th }}$ position. Therefore, corporal punishment was the most frequently used in the secondary schools.

Table 1: Mean ranking of responses of secondary school teachers on the types of punishment used for disciplinary control of secondary school students. $n=250$

\begin{tabular}{llcccc}
\hline Types of Punishment & \multicolumn{2}{c}{ Yes Agreement } & \multicolumn{2}{c}{ No Disagreement } & Rank order \\
& \% & $\mathbf{X}^{-}$ & $\mathbf{\%}$ & $\mathbf{X}^{-}$ & \\
\hline Corporal punishment & 85 & 0.85 & 15 & 0.15 & $1^{\text {st }}$ \\
Sweeping & 82 & 0.82 & 18 & 0.18 & $2^{\text {nd }}$ \\
Grass gutting & 79 & 0.79 & 21 & 0.21 & $3^{\text {rd }}$ \\
Reprimand & 74 & 0.74 & 26 & 0.26 & $4^{\text {th }}$ \\
Abuse & 71 & 0.71 & 29 & 0.29 & $5^{\text {th }}$ \\
Issuing threat & 70 & 0.70 & 30 & 0.30 & $6^{\text {th }}$ \\
Cleaning of toilet & 68 & 0.68 & 32 & 0.32 & $7^{\text {th }}$ \\
Withdrawal of privilege & 66 & 0.66 & 34 & 0.34 & $8^{\text {th }}$ \\
Extra class work & 65 & 0.65 & 35 & 0.35 & $9^{\text {th }}$ \\
Repairing of damaged property & 51 & 0.51 & 49 & 0.49 & $10^{\text {th }}$ \\
Suspension & 43 & 0.43 & 57 & 0.57 & $11^{\text {th }}$ \\
Expulsion & 37 & 0.37 & 63 & 0.63 & $12^{\text {th }}$ \\
Isolation & 33 & 0.33 & 67 & 0.67 & $13^{\text {th }}$ \\
Screaming & 31 & 0.31 & 69 & 0.69 & $14^{\text {th }}$ \\
Stumping & 24 & 0.24 & 76 & 0.76 & $15^{\text {th }}$ \\
Law enforcement agents & 09 & 0.09 & 91 & 0.91 & $16^{\text {th }}$ \\
Detention & 02 & 0.02 & 98 & 0.98 & $17^{\text {th }}$ \\
\hline
\end{tabular}

Source: Field work

\section{Research Question Two}

What is the level of effectiveness of corporal punishment on disciplinary control of secondary school students? Mean was used to rate the responses of secondary school. Summaries of the results were presented on table 2 .

Table 2: Teachers mean rating of the effectiveness of corporal punishment on disciplinary control of secondary school students. $n=250$

\begin{tabular}{lllll}
\hline S/N & Items & $\mathbf{X}$ & SD & Decision \\
\hline 1 & Flogging & 3.36 & 0.54 & Effective \\
2 & Slapping & 2.13 & 0.05 & Not effective \\
3 & Spanking & 2.07 & 0.04 & Not effective \\
4 & Hitting with object & 2.37 & 0.39 & Not effective \\
5 & Punching & 2.29 & 0.37 & Not effective \\
6 & Kicking & 2.18 & 0.08 & Not effective \\
7 & Painful body posture & 3.34 & 0.51 & Effective \\
8 & Kneeling down & 2.98 & 0.79 & Effective \\
9 & Pinching & 2.12 & 0.07 & Not effective \\
10 & Prevention of excretion & 2.06 & 0.30 & Not effective \\
\hline
\end{tabular}

* Mean significant at 2.50 and above

The results presented in table 2 indicated that only three forms of corporal punishment were effective. These include flogging $\overline{(X}=3.36)$; painful body posture $(\bar{X}=3.34)$ and kneeling down $(\bar{X}=$ 2.98). They were considered effective for mean scoring up to 2.50 and above in the teachers rating. 
Others were not effective by reason of mean rating of less than 2.50. The implication of this was that very few forms of corporal punishment were effective while majority were not effective. Therefore, corporal punishment was not effective in disciplinary control of the secondary school students in Calabar Metropolis of Nigeria.

\section{Hypothesis}

There is no significant difference in the use of corporal punishment on disciplinary control between the public and private secondary school students. The independent variable was the use of corporal punishment while the dependent variable was the disciplinary control. The independent t-test statistical analysis was used to compare the mean $(X)$ scores of the two classes of secondary schools in the use of corporal punishment on their disciplinary control of students. Summaries of their results were presented in table 3.

Table 3: Independent t-test analysis of difference in the use of corporal punishment for disciplinary control between public and private owned secondary school students. $n=250$

\begin{tabular}{lllllll}
\hline S/N & Variables & Classification & $\mathbf{N}$ & $\mathbf{X}$ & SD & t-values \\
\hline 1 & Corporal punishment by principals & Public & 130 & 11.77 & 2.67 & \\
& & Private & 120 & 9.80 & 2.14 & $6.43^{*}$ \\
2 & Corporal punishment by teachers & Public & 130 & 11.04 & 2.75 & \\
& & Private & 120 & 8.83 & 2.32 & $6.44^{*}$ \\
& & Total sample & $\mathbf{2 5 0}$ & $\mathbf{2 2 . 6 1}$ & $\mathbf{4 . 3 8}$ & \\
\hline
\end{tabular}

* Significant at $0.05 ; \mathrm{df}=248 ;$ critical t-value $=1.965$

The results of the analysis in table 3 indicated that the calculated t-values of 6.43 for corporal punishment administered by the principals; 6.44 for corporal punishment administered by the teachers. The critical t-value was 1.968 at 0.05 alpha level of significance and with 248 degree of freedom. The calculated t-values were found to be greater than the critical t-value. The interpretation was that the null hypothesis was rejected while the alternate hypothesis was retained. Therefore, there is a significant difference in the use of corporal punishment on disciplinary control between public-owned and privateowned secondary school students.

\section{DISCUSSION OF RESULTS}

The research question one revealed that corporal punishment was the most frequently used type of punishment on the disciplinary control of secondary school students in Calabar Metropolis of Cross River State, Nigeria. This was reflected in the positive affirmation decision of the items of response by the secondary school teachers. The affirmation was explained by the highest percentage of 85 which resulted in the mean of 0.85 with the first rank order. This means that corporal punishment model was a generally acceptable method intentionally applied in promoting good behaviour and decorum into the mischievious heads of school children in the secondary schools. Moreso, teachers and the school heads found students to respond to and think twice before any act of indiscipline because of the use of physical pains to deal with repeated misbehaviour capable of threatening the success of teaching-learning process.
This finding supported the work of Chianu (2001) that students would master their subjects more effectively if teachers gave them doses of corporal punishment. Contrary to this finding, were the views of many researchers. Rigby (2011) observed that corporal punishment has shock and dehumanizing value and made learning environment a punitive place. According to Reyes (2010), fear of physical punishment inhibited creativity in students, damaged teacherstudent relationship and could not effectively change repeated misbehaviour. These controversial issues concerning corporal punishment as a means of disciplinary control in schools necessitated this investigation in order to discuss it rationally and objectively.

The research question two showed that only three forms of corporal punishment were effective while seven forms were ineffective on the disciplinary control of the secondary school students. The implication was that, corporal 
punishment was not effective in the disciplinary control of secondary school students in Calabar Metropolis. The result proved that effective disciplinary control did not rely upon external application of consequences designed to elicit compliance. Desire by the students drove activities since discipline was from within. The finding was in consonance with Nathan (2012) and Squnder (2010). These scholars observed that corporal punishment should be discouraged since students experienced psychological harm because of its endless cycle.

A point was made here that when good judgment was valued over blind obedience, students developed self-dedication which allowed them to forgo short-term pleasure in the pursuit of their educational goals. The use of physical punishment could generate psychological problems in the students such as anxiety, depression, inferiority complex, withdrawal syndrome and aggression among others. These problems contributed to its ineffectiveness on the disciplinary control of the secondary school students.

The independent t-test analysis revealed that there was a significant difference in the use of corporal punishment on disciplinary control between public-owned and private-owned secondary school students. This attested to the fact that the administration of corporal punishment in public secondary schools were different from those of the private schools counterparts on the disciplinary control. This means that the state has legitimate and substantial interest in maintaining order and discipline in both the public and private schools. Also, there was implied obligation imposed upon teachers as agents of the state to exercise discretion in deciding the methods to be used in accomplishing the legitimate and essential purpose of disciplinary control. Anything to the contrary must have been explicitly stated in a statute.

In view of the difficulty by the court in proving rationalization and objectivity of the use of corporal punishment, teachers in secondary schools exercise reasonable care in the use of physical force. According to Nathan (2012), most private schools in Cross River State of Nigeria have policy directives of none or limited infliction of physical chasetisement. Overtime, such directives may have crystallized into a custom in Calabar Metropolis. In that case, parents have limited expectations of their children to be chasetised by the teachers in most private secondary schools in the metropolis.

Fundamentally, private secondary schools operating under business principles, entrenched business intelligence in their disciplinary control since corporal punishment often raised heated debates in most part of the world. However in some cases, troublesome students could make teachers to resist emotionally to the extent of using physical punishment. This could be on the basis that the court upheld the right of teachers and school heads to administer minor punishment in Nigerian schools (Kayode, 2010).

\section{CONCLUSION}

This study has been able to establish that corporal punishment was most frequently applied among other types of punishment on the disciplinary control of secondary school students in Calabar Metropolis of Nigeria. Corporal punishment was not effective on the disciplinary control while there was significance difference in the use of the model between pubic secondary schools and the private schools counterparts. Therefore, there was need to utilize better common method of disciplinary control in order to develop good behaviour for self-dedication in the pursuit of studentsôeducational objectives.

\section{Recommendations}

1. Corporal punishment should be discouraged as a means of disciplinary control in the secondary schools. This is because discipline is from within while physical chastisement aggravate behaviour instead of curbing it.

2. Secondary Education Board, homes and society must close ranks to devise a concrete common method of disciplinary control. This is necessary since corporal punishment most frequently used is not effective

3. Secondary school teachers and administrators should be trained periodically on effective management of human beings. This will improve understanding and appreciation of studentsô behaviour and development vis-à-vis secondary schools as social institutions.

4. School administrators in both public and private secondary schools should engage in regular meetings with their 
school prefects to identify grievances, suggest solutions and communicate tomembers of staff accordingly. This could prevent demonstrations and riots for peaceful teaching-learning environment.

\section{REFERENCES}

Adesina, S., 2008. Planning and Educational Development in Nigeria. Lagos: Educational Industries Ltd.

Chianu, E., 2001. Corporal Punishment in Primary and Secondary Schools: Legal Position. Asaba: Endless Books Publishers.

Kayode, A., 2010. Legal Obligation and Contractual Rights of Secondary School Teachers in Nigeria Secondary Education. Ile Ife: University of lle Ife Press.
Nathan, S. A., 2012. The Role of Pediatrics in Abolishing Corporal Punishment in Schools. Journal of Medical Law 9(2), 142-156.

Reyes, A. H., 2010. Discipline, Achievement and Race: Is Zero Tolerance the Answer? Journal of Adolescent Health 13(8), 239245.

Rigby, K., 2011. Bullying in Schools and What to do about it. London: Jessica Kigsley.

Saunder, F., 2003. An Analysis of the Arguments for and against the use of Corporal Punishment in Kenya Secondary Schools. Kenya Journal of Educational Research 7(1), 60-73.

Squnder, M., 2010. Troublesome Behavior in the Classroom $\left(4^{\text {th }} \mathrm{Ed}\right)$. London: Routledge. 